\title{
Prevalence of Elevated Glycated Hemoglobin Concentrations in the Polycystic Ovary Syndrome: Anthropometrical and Metabolic Relationship in Amazonian Women
}

\author{
Sebastiao Freitas de Medeiros ${ }^{\mathrm{a}, \mathrm{b}, \mathrm{c}}$, Marcia Marly Winck Yamamoto ${ }^{\mathrm{a}, \mathrm{b}}$, \\ Herica Bernardes Bueno ${ }^{\mathrm{a}}$, Danilla Belizario ${ }^{\mathrm{a}}$, Jacklyne Silva Barbosa ${ }^{\mathrm{b}}$
}

\begin{abstract}
Background: To determine the prevalence of elevated glycated hemoglobin $(\mathrm{HbAlc})$ and to examine its relationship with other carbohydrate metabolic parameter among Brazilian women with polycystic ovary syndrome (PCOS).
\end{abstract}

Methods: A cross-sectional study including 288 PCOS patients was conducted. Anthropometrical, clinical, biochemical and endocrine parameters were evaluated.

Results: The mean age was $26.92 \pm 5.51$ years. HbA1c mean concentration was $5.83 \pm 1.34 \%$. In $38.54 \%$ of patients, HbAlc was $\geq 5.7 \%$. HbAlc was positively correlated with body weight $(\mathrm{r}=$ $0.142, \mathrm{P}=0.017)$, body mass index $(\mathrm{P}=0.000)$, waist:hip ratio $(\mathrm{P}=$ $0.000)$, fat mass $(\mathrm{P}=0.000)$, conicity index $(\mathrm{P}=0.000)$, triglyceride $(\mathrm{P}=0.001), \mathrm{C}$-peptide $(\mathrm{P}=0.000)$, total testosterone $(\mathrm{P}=0.003)$, free testosterone $(\mathrm{P}=0.000)$, free androgen index $(\mathrm{P}=0.006)$ and fasting insulin $(\mathrm{P}=0.025)$. Using the oral glucose tolerance test, HbA1c showed positive correlation with glucose concentrations at any point in time $(\mathrm{P}<0.05)$.

Conclusions: $\mathrm{HbA} 1 \mathrm{c}$ was elevated in nearly $40 \%$ of PCOS patients and it showed positive correlation with several anthropometric and metabolic factors and androgen levels. The current study provides further evidence that $\mathrm{HbA} 1 \mathrm{C}$ is higher in PCOS patients and may have a potential role in the prediction of dysglycemic disease in these women.

Keywords: Glycated hemoglobin; Impaired glucose tolerance; Polycystic ovary syndrome

\footnotetext{
Manuscript accepted for publication April 10, 2014

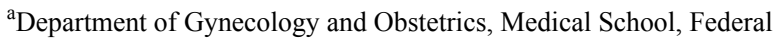
University of Mato Grosso, 78055-728 Cuiaba, MT, Brazil

${ }^{\mathrm{b}}$ Tropical Institute of Reproductive Medicine and Menopause, 78043-306 Cuiaba, MT, Brazil

${ }^{\mathrm{c}}$ Corresponding author: Sebastiao Freitas de Medeiros, Almirante Henrique Pinheiro Guedes, 195, Duque de Caxias, 78043-306 Cuiaba, MT, Brazil. Email: de.medeiros@terra.com.br
}

doi: http://dx.doi.org/10.14740/jocmr1829w

\section{Introduction}

Polycystic ovary syndrome (PCOS) is the most common endocrinopathy in women of reproductive age, affecting up to $21 \%$ of patients [1]; its prevalence in Brazilian women was not determined yet. Compared with healthy women, patients with PCOS are at a higher risk for coronary heart disease $(\mathrm{OR}=1.2$ - 12.9), cerebrovascular disease $(\mathrm{OR}=2.8-3.4)$, hypertension $(\mathrm{OR}=1.4)$, dyslipidemia $(\mathrm{OR}=2.9-3.2)$, myocardial infarction $(\mathrm{OR}=2.6-4.2)$, impaired glucose tolerance (IGT) $(\mathrm{OR}=2.5)$, metabolic syndrome $(\mathrm{OR}=2.1)$ and central obesity $(\mathrm{OR}=1.9-2.4)$ [2-5]. The risk for type 2 diabetes mellitus (T2DM) is also two- to four-fold higher in patients with PCOS $(\mathrm{OR}=2.2$ - 3.6). The current screening recommendations for T2DM in patients with PCOS include the measurement of fasting plasma glucose (FPG) and the use of an oral glucose tolerance test (oGTT, $75 \mathrm{~g}$ oral dextrose) in cases of obesity, advanced age, personal history of gestacional diabetes or family history of T2DM [6]. The measurement of glycated hemoglobin $(\mathrm{HbAlc})$ is also commonly used to identify non-PCOS individuals at risk of IGT, prediabetes or T2DM [7]. As the use of HbA1c does not require fasting and provides a time-averaged estimate of blood glucose over the preceding $3-12$ weeks [8], it may be a better indicator of overall glycemia than a glucose concentration at a single point in time $[9,10]$.

Elevated $\mathrm{HbA} 1 \mathrm{c}$ concentrations have been associated with other risk factors for cardiovascular disease (CVD) and the presence of metabolic syndrome in several other nonPCOS clinical conditions and populations [8]. It seems that in patients with or without PCOS, a $1 \%$ increase in the absolute $\mathrm{HbA} 1 \mathrm{c}$ concentration is associated with a $10-20 \%$ increase in CVD risk $[8,11]$. The prevalence of elevated HbAlc in women with PCOS has not yet been established worldwide. Previous studies have reported that elevated $\mathrm{HbAlc}$ occurs in $10 \%$ of PCOS patients in Austria and Turkey $[10,12]$ and $31 \%$ of Korean patients [13]. Given the potential relationships between $\mathrm{HbAlc}$ and health-related outcomes in PCOS patients, and the fact that a very few studies have reported on the prevalence and of abnormal $\mathrm{HbA} 1 \mathrm{c}$ concentrations in patients with PCOS, the current study aimed to determined the 
prevalence of elevated $\mathrm{HbA} 1 \mathrm{c}$ concentrations in knowledge Brazilian patients with this clinical condition.

\section{Materials and Methods}

The sample consisted of PCOS patients in whom HbA1c levels were measured attending either the Endocrinology or the Reproductive Units at the Julio Muller University Hospital and Tropical Institute of Reproductive and Menopause in Cuiaba, Brazil, until July 2013. The sample size was estimated using an imprecision (i) value of 5\%, a mean expected effect of $14 \%$ (based on scarce previous studies reporting on the proportion of PCOS patients with an elevated $\mathrm{HbA} 1 \mathrm{c}$ ) and an alpha level of 5\% [10, 14, 15]. Written informed consent was obtained from each patient, as approved by the local Committee for Ethics in Research. Patients were excluded for any of the following reasons: use of sex steroids or insulin-sensitizing drugs over the previous 6 months; thyroxin-stimulating hormone $(\mathrm{TSH})$ concentration $\geq 4.2 \mu \mathrm{UI} /$ $\mathrm{mL}$ and prolactin (PRL) concentration $>25 \mathrm{ng} / \mathrm{mL}(1,086$ $\mathrm{nmol} / \mathrm{L})$. Non-classic 21-hydroxylase, 11 3 -hydroxylase and $3 \beta$-hydroxysteroid dehydrogenase ( $3 \beta$-HSD) were excluded as published elsewhere [15].

PCOS diagnosis was performed according to the National Institutes of Health and Rotterdam criteria [1, 15]. Clinical hyperandrogenism was defined as a dichotomous variable using the presence or not of hirsutism in the following body areas: upper lip, chin, chest, upper or lower back, upper or lower abdomen, upper arms and thighs [16]. The free androgen index (FAI) was estimated as total testosterone $(\mathrm{nmol} / \mathrm{L}) / \mathrm{sex}$ hormone-binding globulin $(\mathrm{SHBG} ; \mathrm{nmol} / \mathrm{L}) \times$ 100. The free estrogen index (FEI) was calculated as follows: $100 \times$ estradiol $(\mathrm{nmol} / \mathrm{L}) / 272.1 \times \mathrm{SHBG}$ nmol/L) [17]. Ovary transvaginal ultrasound examination was performed using a Voluson machine (Voluson ${ }^{8} E 8$, GE Health Care, England) and PCO morphology defined as previous recommendation [18].

\section{Anthropometric measures}

Subjects were weighed on an electronic scale, and height was measured using a Harpender stadiometer (Holtain Limited, Crymych, Dyfed, UK). The waist circumference (WC) was measured at the midway point between the lower rib margin and the iliac crest, and the hip was measured at the widest circumference (location of the greater trochanters). Body mass index (BMI) was calculated as body weight $(\mathrm{kg} / \mathrm{height}$ $\left.(\mathrm{m})^{2}\right)$. Obesity was defined as BMI $\geq 30\left(\mathrm{~kg} / \mathrm{m}^{2}\right)$ [4]. Lean body mass (LBM) was calculated using the James equation: $(1.07 \times$ weight $(\mathrm{kg}))-148 \times\left(\right.$ weight $^{2} /(100 \times \text { height }(\mathrm{m}))^{2}$ [19]. Fat mass (FM) was calculated as: body weight - LBM. Abdominal adiposity was estimated using the conicity index $(\mathrm{C}$ index $): \mathrm{WC}(\mathrm{m}) /(0.109 \times$ square root of body weight $(\mathrm{kg}) /$ height (m)) [20].

\section{Biochemical analysis}

Triglycerides (TG), high-density lipoprotein cholesterol (HDL-C) and total cholesterol (TC) were measured after a 12-h overnight fast using an enzymatic assay (Wiener Laboratories, Rosario, Argentina). Low-density lipoprotein cholesterol (LDL-C) was calculated as TC - (HDL-C $+\mathrm{TG} / 5)$ [21]. On a different day, blood was collected for the biochemical and endocrine measurements, followed by a 3-h oGTT and samples obtained basally and at 30, 60, 90, 120 and $180 \mathrm{~min}$ after dextrose ingest. Blood samples were drawn between days 3 and 5 in patients with oligomenorrhea or, in amenorrheic patients, in a random day, including progesterone measurement to certify that the blood was collected in follicular phase. The plasma glucose concentration was analyzed using the glucose oxidase technique (Beckman Glucose Analyses, Fullerton, CA, USA). HbA1c was measured using a turbidimetric assay (Wiener Laboratories, Rosario, Argentina). The criteria of elevated HbA1c concentration $(\geq 5.7 \%$ ) with a threshold of $\geq 6.5 \%$ to diagnose T2DM were used as recommended by the American Diabetes Association [7]. IGT or prediabetes were defined by a single abnormal parameter as follows: FPG between $100 \mathrm{mg} / \mathrm{dL}(5.5$ $\mathrm{mmol} / \mathrm{L})$ and $126 \mathrm{mg} / \mathrm{dL}(6.99 \mathrm{mmol} / \mathrm{L}) ; 2-\mathrm{h}$ oGTT glucose value between $140 \mathrm{mg} / \mathrm{dL}(7.8 \mathrm{nmol} / \mathrm{L})$ and $199 \mathrm{mg} / \mathrm{dL}(11.0$ $\mathrm{nmol} / \mathrm{L}$ ) [7]. Insulin resistance was defined using fasting insulin levels $>12.2 \mu \mathrm{U} / \mathrm{mL}(84.7 \mathrm{pmol} / \mathrm{L})$ [22]; and/or homeostasis model assessment of insulin resistance (HOMAIR) $\geq 2.8$ [23]. The homeostatic model for insulin resistance and tissue sensitivity to insulin (HOMA-IR) was calculated using a free online program [23]: (glucose $(\mathrm{nmol} / \mathrm{L}) \times$ insulin $(\mu \mathrm{U} / \mathrm{mL})) / 22.5$.

\section{Hormone assays}

Hormones were measured as described elsewhere [18]. In short, serum luteinizing hormone ( $\mathrm{LH})$, follicle-stimulating hormone (FSH), TSH, estradiol, PRL, SHBG and total testosterone levels were measured by electrochemiluminescence assays (Elecsys 2010, Roche Diagnostics GMBH, Mannhein, German). Free testosterone and insulin were measured using a chemiluminescence assay (Siemens Medical Solution Diagnostics, CA, USA) with sensitivity and intra- and inter-assay coefficients of variation as the following: $0.002 \mathrm{pmol} / \mathrm{L}, 7.0-8.4 \%$ for free testosterone and $2 \mu \mathrm{UI} / \mathrm{mL}$, 4.9-6.4\% for insulin.

\section{Statistical analyses}

Data were examined for Gaussian distribution using the Kolmogorov-Smirnov-Lilliefors goodness of fit test, and, where necessary, data were log transformed prior to analysis and 
Table 1. Sociodemographic and Clinical Characteristics of Brazilian Polycystic Ovary Syndrome Patients

$\begin{array}{lll}\text { Parameters } & \text { N (288) }\end{array}$

Age (years)

$\begin{array}{lll}14-19 & 28 & 9.72 \\ 20-24 & 64 & 22.22 \\ 25-29 & 100 & 34.72 \\ 30-34 & 76 & 26.38 \\ 35-39 & 17 & 5.90 \\ \geq 40 & 3 & 1.04\end{array}$

Social habits

Etilism

Smoking

None

Physical activity

Walking

Biking

Other

4

1.39

None

Not recorded

Clinical features

Infertility

Amenorrhea

Oligomenorrhea

Polymenorrhea

Acne

Hirsutism

Acanthosis nigricans

Striaes

Ultrasound features

$$
\begin{aligned}
& \text { Normal ovary } \\
& \text { Polycystic ovary }
\end{aligned}
$$


Table 2. Distribution of Normal and Abnormal Anthropometrical Characteristics of Polycystic Ovary Syndrome Patients

\begin{tabular}{|c|c|c|c|c|}
\hline Variable & $\mathbf{n} / \mathbf{N}$ & $\%$ & Test $\mathrm{Z}$ & $\mathbf{P} *$ \\
\hline \multicolumn{5}{|l|}{ BMI $\left(\mathrm{kg} / \mathrm{m}^{2}\right)$} \\
\hline$<30$ & $147 / 264$ & 56.68 & & \\
\hline$\geq 30$ & $117 / 264$ & 44.32 & 2.611 & 0.009 \\
\hline \multicolumn{5}{|l|}{ Fat mass $(\%)$} \\
\hline$<32$ & $146 / 265$ & 55.10 & & \\
\hline$>32$ & $119 / 265$ & 44.90 & 2.345 & 0.018 \\
\hline \multicolumn{5}{|l|}{ Waist (cm) } \\
\hline$<88$ & $129 / 254$ & 50.79 & & \\
\hline$\geq 88$ & $125 / 254$ & 49.21 & 0.354 & 0.726 \\
\hline \multicolumn{5}{|l|}{$\mathrm{W}: \mathrm{H}$ ratio } \\
\hline$<0.80$ & $191 / 252$ & 75.80 & & \\
\hline$\geq 0.80$ & $61 / 252$ & 24.20 & 11.581 & 0.000 \\
\hline \multicolumn{5}{|c|}{ Conicity index } \\
\hline$<1.25$ & $112 / 150$ & 74.67 & & \\
\hline$\geq 1.25$ & $38 / 150$ & 25.33 & 8.544 & 0.000 \\
\hline
\end{tabular}

${ }^{*} \mathrm{P}$, two-tailed Z proportion test.

subsequently retransformed into the original units for reporting. Anthropometrical, biochemical and endocrine data, presented as mean and standard deviation (SD), were analyzed using the Welch test because equality of variance was not tested. The $\mathrm{Z}$ test was used to compare $\mathrm{HbA} 1 \mathrm{c}$ status in obese and non-obese PCOS patients. The prevalence rate with $95 \%$ confidence intervals $(95 \% \mathrm{CI})$ was used to compare HbAlc status and other markers of glucose metabolism. The relationships between the HbAlc concentration and anthropometrical, endocrine and metabolic variables were examined using Pearson's correlation coefficient. Stratified analyses for confounding variables were performed using the MantelHaenzel $\chi^{2}$ test. All analyses were performed using SPSS for Windows, version 18 (SPSS Inc., Chicago, IL, USA). Statistical significance was set at $\mathrm{P} \leq 0.05$.

\section{Results}

Of the 288 PCOS patients enrolled, 197 (68.4\%) were Cau- casian, 41 (14.2\%) were African descendants, 41 (14.2\%) were of "other" races and nine (3.1\%) did not declare their ethnicity. The mean age was $26.92 \pm 5.51$ years. Sociodemographic and clinical characteristics are shown in Table 1. The BMI was $29.94 \pm 7.0 \mathrm{~kg} / \mathrm{m}^{2}$, FM $30.3 \pm 12.54 \mathrm{~kg}$, waist circumference $88 \pm 16.31 \mathrm{~cm}$, waist:hip ratio $0.81 \pm 0.08$ and conicity index $1.16 \pm 0.11$. The stratified anthropometric features are depicted in Table 2. The overall mean HbA1c concentration was $5.83 \pm 1.34 \%$. HbA1c values $\geq 5.7 \%$ were present in $111 / 288(38.54 \%)$, in which $102(35.4 \%)$ had $\mathrm{HbA} 1 \mathrm{c}$ between $5.7 \%$ and $6.4 \%$ and nine $(3.12 \%)$ had $\mathrm{HbAlc}$ $\geq 6.5 \%$. In 177/288 (61.46\%), the HbA1c were $<5.7 \%$. After stratification, the associations between $\mathrm{HbA} 1 \mathrm{c}$ and other glucose metabolic parameters are shown in Table 3. Overall FPG levels presented mean of $5.11 \pm 0.78 \mathrm{mmol} / \mathrm{L}$; its levels were $<5.55 \mathrm{mmol} / \mathrm{L}$ in $234 / 282(82.9 \%)$ patients, between $5.55 \mathrm{mmol} / \mathrm{L}$ and $6.99 \mathrm{mmol} / \mathrm{L}$ in $39 / 282(13.8 \%)$ and $>6.99$ $\mathrm{mmol} / \mathrm{L}$ in $9 / 282(3.19 \%)$ patients. Fasting insulin presented mean of $87.70 \pm 2.69$ and the levels were $>85 \mathrm{nmol} / \mathrm{L}$ in $142 / 265(53.5 \%)$ patients. The mean HOMA-IR was 1.93 
Table 3. Analysis of the Association of Glycated Hemoglobin Concentrations With Other Carbohydrate Metabolism Parameters in Polycystic Ovary Syndrome

\begin{tabular}{|c|c|c|c|c|c|}
\hline \multirow{2}{*}{ Variable } & \multicolumn{2}{|l|}{ HbA1c } & \multirow{2}{*}{ Total (n) } & \multirow{2}{*}{$P R *(95 \%$ CI) } & \multirow{2}{*}{$\mathbf{P}^{* *}$} \\
\hline & $\geq 5.7$ (n) & $<5.7(\mathrm{n})$ & & & \\
\hline \multicolumn{6}{|c|}{ Fasting glucose $(\mathrm{nmol} / \mathrm{L})$} \\
\hline$\geq 5.55$ & 35 & 13 & 48 & & \\
\hline$<5.55$ & 76 & 158 & 234 & $2.24(1.68-2.76)$ & 0.000 \\
\hline Total & 111 & 171 & 282 & & \\
\hline \multicolumn{6}{|c|}{ Fasting insulin $(\mathrm{nmol} / \mathrm{L})$} \\
\hline$\geq 85$ & 69 & 73 & 142 & & \\
\hline$<85$ & 37 & 86 & 123 & $1.61(1.16-2.27)$ & 0.003 \\
\hline Total & 106 & 159 & 265 & & \\
\hline \multicolumn{6}{|c|}{ Pep-C (nmol/L) } \\
\hline$\geq 1.17$ & 26 & 17 & 43 & & \\
\hline$<1.17$ & 60 & 112 & 172 & $1.73(1.19-2.32)$ & 0.003 \\
\hline Total & 86 & 129 & 215 & & \\
\hline \multicolumn{6}{|l|}{ HOMA-IR } \\
\hline$\geq 2.8$ & 31 & 26 & 57 & & \\
\hline$<2.8$ & 75 & 127 & 202 & $1.46(1.04-1.95)$ & 0.022 \\
\hline Total & 106 & 153 & 259 & & \\
\hline \multicolumn{6}{|l|}{ HOMA $\% \beta$} \\
\hline$\geq 155$ & 41 & 52 & 93 & & \\
\hline$<155$ & 65 & 101 & 166 & $1.12(0.81-1.53)$ & 0.510 \\
\hline Total & 106 & 153 & 259 & & \\
\hline
\end{tabular}

${ }^{*} \mathrm{PR}$ : prevalence ratio. ${ }^{* *} \mathrm{P}$, two-tailed $\mathrm{Z}$ proportion test.

\pm 1.21 and the levels were $>2.8 \%$ in $57 / 259(22.0 \%)$ patients, the mean HOMA- $\beta$ was $128.73 \pm 1.52$ and $<155 \%$ in $166 / 259$ (64.1\%) and the C-peptide concentrations were 0.82 $\pm 0.39 \mathrm{nmol} / \mathrm{L}$ and $>1.17 \mathrm{nmol} / \mathrm{L}$ in $43 / 215(20 \%)$ patients.

$\mathrm{HbAlc}$ concentrations were positively associated with several anthropometrical (body weight, $\mathrm{r}=0.142, \mathrm{P}=0.017$; BMI, $\mathrm{r}=0.265, \mathrm{P}=0.000$; waist:hip, $\mathrm{r}=0.271, \mathrm{P}=0.000$; $\mathrm{FM}, \mathrm{r}=0.215, \mathrm{P}=0.000$ ); endocrine (C-peptide, $\mathrm{r}=0.238$,
$\mathrm{P}=0.000 ;$ total $\mathrm{T}, \mathrm{r}=0.179, \mathrm{P}=0.003$; free testosterone, $\mathrm{r}=$ $0.447, \mathrm{P}=0.000$; FAI, $\mathrm{r}=0.1711, \mathrm{P}=0.018$; FEI, $\mathrm{r}=0.167$, $\mathrm{P}=0.055)$; and metabolic $(\mathrm{TG}, \mathrm{r}=0.207, \mathrm{P}=0.001)$ variables. HbAlc was correlated with glucose in the fasting state and any time point after the glucose load (Fig. 1, panel A) but was not correlated with insulin at any of the oGTT time points (Fig. 1, panel B). The distribution of HbA1c levels according the age and BMI is presented in Table 4. 
Panel A
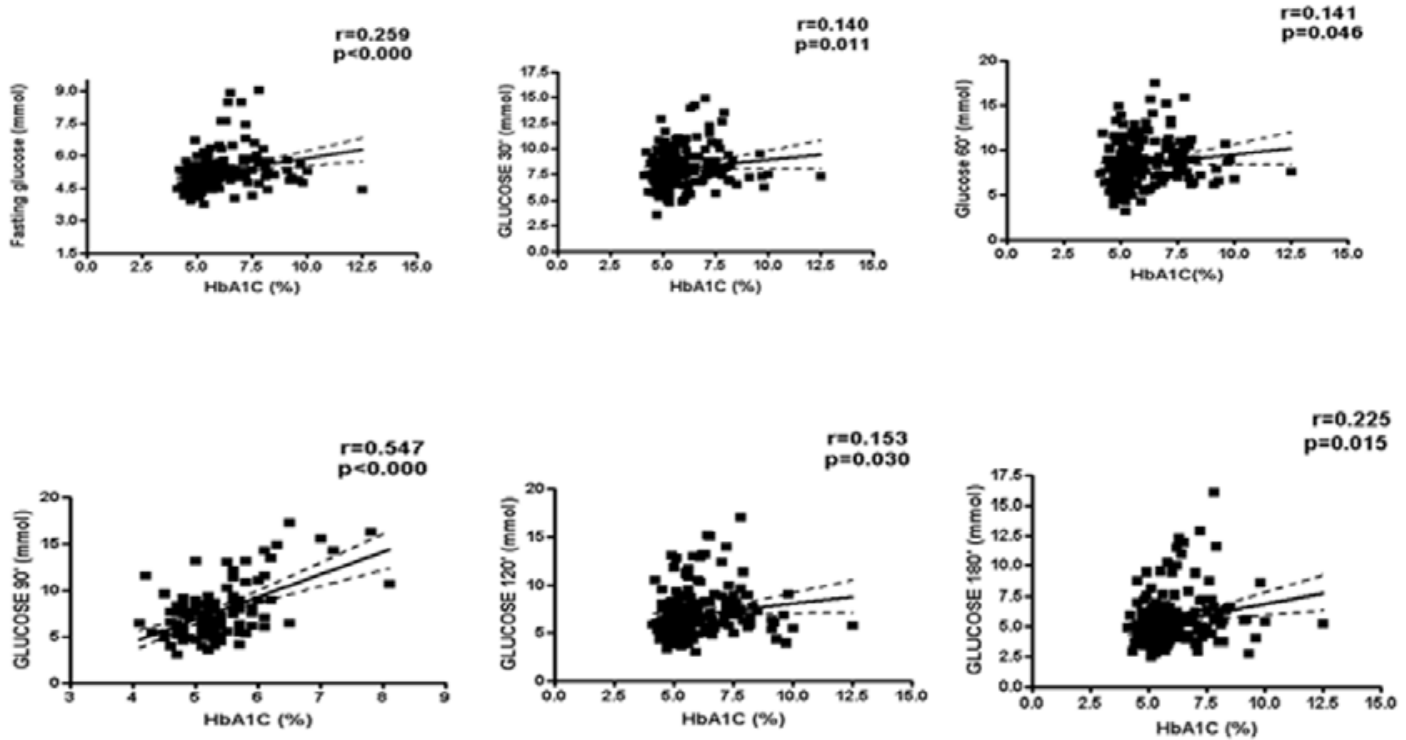

Panel B
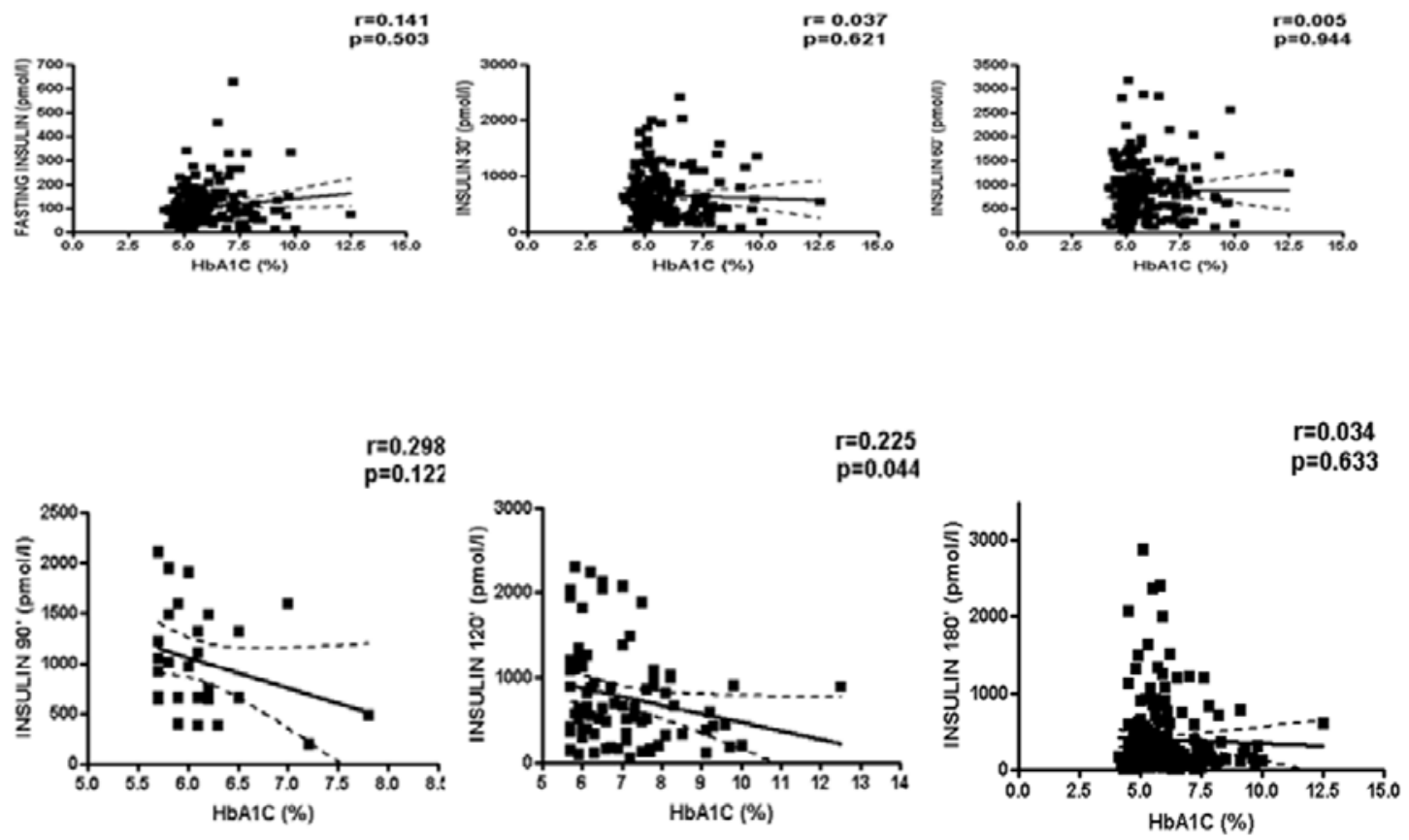

Figure 1. Correlation of glycated hemoglobin $(\mathrm{HbA} 1 \mathrm{c})$ with glucose and insulin.

\section{Discussion}

Elevated $\mathrm{HbA} 1 \mathrm{c}$ concentrations were found in $38 \%$ of PCOS patients, and, after stratification, its levels were not significantly influenced by age or BMI. HbA1c was correlated with a number of variables that are associated with the metabolic syndrome, including fasting glucose and glucose response after oGTT at any point in time. The proportion of PCOS patients with elevated $\mathrm{HbA} 1 \mathrm{c}$ levels in the current study was higher than those found in previous reports in other populations. In Korean PCOS patients, also using $\mathrm{HbAlc} \geq 5.7 \%$ to discriminate normal and high levels, $31 \%$ of the patients had elevated $\mathrm{HbAlc}$, which was significantly higher than the 
Table 4. Stratified Analysis of Glycated Hemoglobin Status According to Age and Body Mass Index in Polycystic Ovary Syndrome

\begin{tabular}{|c|c|c|c|c|c|}
\hline Age (years) & BMI $\geq 30$ (n) & BMI $<30$ (n) & Total (n) & $\chi_{\mathrm{mh}}^{2}$ & $\mathbf{P}$ \\
\hline \multicolumn{6}{|c|}{$\mathrm{HbA} 1 \mathrm{c}<5.7 \%$} \\
\hline$<30$ & 18 & 31 & 49 & & \\
\hline$\geq 30$ & 35 & 78 & 113 & 0.512 & 0.474 \\
\hline Total & 53 & 109 & 162 & & \\
\hline \multicolumn{6}{|c|}{$\mathrm{HbAlc} \geq 5.7 \%$} \\
\hline$<30$ & 31 & 10 & 41 & & \\
\hline$\geq 30$ & 33 & 28 & 61 & 4.806 & 0.028 \\
\hline Total & 64 & 38 & 102 & & \\
\hline \multicolumn{6}{|l|}{ Total } \\
\hline$<30$ & 49 & 41 & 90 & & \\
\hline$\geq 30$ & 68 & 106 & 174 & 5.653 & 0.017 \\
\hline Total & 117 & 147 & 264 & & \\
\hline
\end{tabular}

$X_{m h}^{2}:$ Mantel-Haenszel qui-square.

results observed in healthy controls (6.6\%) [11]. Meanwhile, only $7.6 \%$ of Turkish PCOS patients had HbAlc $>5.6 \%$ [12], and $8.6 \%$ of an older group of Danish PCOS patients presented $\mathrm{HbA} 1 \mathrm{c} \geq 6 \%$ [24]. Interestingly, $20 \%$ of the nonobese patients with PCOS had elevated HbA1c levels in the Korean study, compared to only $6 \%$ of the obese PCOS patients [11]. In contrast, the current study found that the levels were twofold higher in obese than non-obese PCOS patients. This difference was no longer present when the sample was stratified according to the HbAlc levels. At this time, it is difficult to determine if the differences between the Korean, Danish, Turkish and Brazilian patients are due to ethnicity or other sample characteristics.

Elevated $\mathrm{HbA} 1 \mathrm{c}$ levels have been associated with a more adverse metabolic profile, in PCOS patients in the current study and in the study conducted in Denmark [24]. Although no relationships between $\mathrm{HbA} 1 \mathrm{c}$ and insulin either in fasting or after oGTT in the current study was found, such relationships have been reported in the Danish population of PCOS patients [24]. Certainly, more studies are required to confirm the clinical relevance of these data. Significantly higher FAI and free testosterone levels have been reported in women with PCOS and T2DM compared to PCOS women with prediabetes or normal glucose tolerance [10], and significant correlations between $\mathrm{HbA1c}$ and FAI and free testosterone have been reported in women with reduced fertility [25]. The study conducted in Danish PCOS patients reported conflicting findings; total testosterone and FAI were not positively correlated with $\mathrm{HbA} 1 \mathrm{c}$ levels. The authors suggested that the combination of high HbAlc and low SHBG levels could be better as markers for CVD risk in PCOS patients, based on the presence of inverse relationships between SHBG and $\mathrm{HbAlc}$ levels in their sample. Therefore, the influence of age, BMI and endocrinological features on HbAlc concentrations should be examined in future studies and in different populations.

Increased HbAlc levels could potentially be used as a marker of cardiovascular risk in individuals without diabetes [26]. The significant correlations between HbA1c levels and several established anthropometrical predictors of CVD risk in the present study are in agreement with the reported cardiovascular risk in other non-PCOS populations with central obesity, IFG, increased carotid to femoral pulse wave velocity, or low fecund ability rate [5, 27-30]. Within the PCOS 
population, a recent study reported associations between elevated $\mathrm{HbA} 1 \mathrm{c}$ concentrations, larger waist circumferences and higher BMIs in an older group of PCOS patients [24].

One possible limitation of the current study is that social habits that may also affect glycemic status, such as smoking, alcohol use and physical activity, were not completely examined. Second, the study enrolled women who were attending tertiary institutions, and this may have resulted in selection bias and limited the generalizability to the general community. Finally, most of the patients included in the present study met all three Rotterdam criteria for PCOS diagnosis, and this may explain the high prevalence of elevated $\mathrm{HbAlc}$ in this sample. In conclusion, HbA1c was elevated in at least onethird of PCOS patients and was positively associated with weight, BMI, waist:hip ratio, FM and androgen levels in the current study. Future clinical studies should be conducted to better understand the potential role of $\mathrm{HbA} 1 \mathrm{c}$ as a dysmetabolic variable and a marker of elevated CVD risk in PCOS patients.

\section{Acknowledgement}

The authors thank American Journal Experts for criticism and English review of the manuscript.

\section{Conflict of Interest}

The authors declare that they have no conflict of interest.

\section{References}

1. March WA, Moore VM, Willson KJ, Phillips DI, Norman RJ, Davies MJ. The prevalence of polycystic ovary syndrome in a community sample assessed under contrasting diagnostic criteria. Hum Reprod. 2010;25(2):544551.

2. Wild S, Pierpoint T, McKeigue P, Jacobs H. Cardiovascular disease in women with polycystic ovary syndrome at long-term follow-up: a retrospective cohort study. Clin Endocrinol (Oxf). 2000;52(5):595-600.

3. Moran LJ, Misso ML, Wild RA, Norman RJ. Impaired glucose tolerance, type 2 diabetes and metabolic syndrome in polycystic ovary syndrome: a systematic review and meta-analysis. Hum Reprod Update. 2010;16(4):347-363.

4. de Groot PC, Dekkers OM, Romijn JA, Dieben SW, Helmerhorst FM. PCOS, coronary heart disease, stroke and the influence of obesity: a systematic review and metaanalysis. Hum Reprod Update. 2011;17(4):495-500.

5. Lim SS, Davies MJ, Norman RJ, Moran LJ. Overweight, obesity and central obesity in women with polycystic ovary syndrome: a systematic review and meta-analysis. Hum Reprod Update. 2012;18(6):618-637.

6. Mani H, Levy MJ, Davies MJ, Morris DH, Gray LJ, Bankart J, Blackledge H, et al. Diabetes and cardiovascular events in women with polycystic ovary syndrome: a 20-year retrospective cohort study. Clin Endocrinol (Oxf). 2013;78(6):926-934.

7. Standards of medical care in diabetes--2013. Diabetes Care. 2013;36(Suppl 1):S11-66.

8. Peters AL, Davidson MB, Schriger DL, Hasselblad V. A clinical approach for the diagnosis of diabetes mellitus: an analysis using glycosylated hemoglobin levels. Meta-analysis Research Group on the Diagnosis of Diabetes Using Glycated Hemoglobin Levels. JAMA. 1996;276(15):1246-1252.

9. Nathan DM, Turgeon H, Regan S. Relationship between glycated haemoglobin levels and mean glucose levels over time. Diabetologia. 2007;50(11):2239-2244.

10. Lerchbaum E, Schwetz V, Giuliani A, Obermayer-Pietsch B. Assessment of glucose metabolism in polycystic ovary syndrome: $\mathrm{HbAlc}$ or fasting glucose compared with the oral glucose tolerance test as a screening method. Hum Reprod. 2013;28(9):2537-2544.

11. Kim JJ, Choi YM, Cho YM, Jung HS, Chae SJ, Hwang KR, Hwang SS, et al. Prevalence of elevated glycated hemoglobin in women with polycystic ovary syndrome. Hum Reprod. 2012;27(5):1439-1444.

12. Celik C, Abali R, Bastu E, Tasdemir N, Tasdemir UG, Gul A. Assessment of impaired glucose tolerance prevalence with hemoglobin A(1)c and oral glucose tolerance test in 252 Turkish women with polycystic ovary syndrome: a prospective, controlled study. Hum Reprod. 2013;28(4):1062-1068.

13. Kim HK, Bae SJ, Choe J. Impact of HbAlc Criterion on the Detection of Subjects with Increased Risk for Diabetes among Health Check-Up Recipients in Korea. Diabetes Metab J. 2012;36(2):151-156.

14. Lwanga SK, Lemeshow S. World Health Organization: Sample size determination in health studies. A practical manual. World Health Organization, Geneva, 1991.

15. de Medeiros SF, Gil-Junior AB, Barbosa JS, Isaias ED, Yamamoto MM. New insights into steroidogenesis in normo- and hyperandrogenic polycystic ovary syndrome patients. Arq Bras Endocrinol Metabol. 2013;57(6):437444.

16. Wild RA, Vesely S, Beebe L, Whitsett T, Owen W. Ferriman Gallwey self-scoring I: performance assessment in women with polycystic ovary syndrome. J Clin Endocrinol Metab. 2005;90(7):4112-4114.

17. Sowers M, Derby C, Jannausch ML, Torrens JI, Pasternak R. Insulin resistance, hemostatic factors, and hormone interactions in pre- and perimenopausal women: SWAN. J Clin Endocrinol Metab. 2003;88(10):49044910. 
18. Lujan ME, Jarrett BY, Brooks ED, Reines JK, Peppin AK, Muhn N, Haider E, et al. Updated ultrasound criteria for polycystic ovary syndrome: reliable thresholds for elevated follicle population and ovarian volume. Hum Reprod. 2013;28(5):1361-1368.

19. James WPT. Department of Health and Social Security and Medical Research Council Group. Research on obesity. A repot of the DHSS/MRC group. Her Majesty's Stationary office: London, 1976.

20. Valdez R. A simple model-based index of abdominal adiposity. J Clin Epidemiol. 1991;44(9):955-956.

21. Friedewald WT, Levy RI, Fredrickson DS. Estimation of the concentration of low-density lipoprotein cholesterol in plasma, without use of the preparative ultracentrifuge. Clin Chem. 1972;18(6):499-502.

22. McAuley KA, Williams SM, Mann JI, Walker RJ, Lewis-Barned NJ, Temple LA, Duncan AW. Diagnosing insulin resistance in the general population. Diabetes Care. 2001;24(3):460-464.

23. Diabetes Trial Unit: The Oxford Centre for Diabetes, Endocrinology and Metabolism. Oxford, UK: Oxford University; Available from: http://www.dtu.ox.ac.uk/ homacalculator (2013). Accessed 1 May 2013.

24. Velling Magnussen L, Mumm H, Andersen M, Glintborg D. Hemoglobin A1c as a tool for the diagnosis of type 2 diabetes in 208 premenopausal women with polycystic ovary syndrome. Fertil Steril. 2011;96(5):1275-1280.

25. Hjollund NH, Jensen TK, Bonde JP, Henriksen TB, Andersson AM, Skakkebaek NE. Is glycosylated haemoglobin a marker of fertility? A follow-up study of first-pregnancy planners. Hum Reprod. 1999;14(6):1478-1482.

26. Adams RJ, Appleton SL, Hill CL, Wilson DH, Taylor AW, Chittleborough CR, Gill TK, et al. Independent association of $\mathrm{HbA}(1 \mathrm{c})$ and incident cardiovascular disease in people without diabetes. Obesity (Silver Spring). 2009; 17(3):559-563.

27. Lord J, Thomas R, Fox B, Acharya U, Wilkin T. The central issue? Visceral fat mass is a good marker of insulin resistance and metabolic disturbance in women with polycystic ovary syndrome. BJOG. 2006;113(10):12031209.

28. Gluszak O, Stopinska-Gluszak U, Glinicki P, Kapuscinska R, Snochowska H, Zgliczynski W, Debski R. Phenotype and metabolic disorders in polycystic ovary syndrome. ISRN Endocrinol. 2012;2012:569862.

29. Liang J, Zhou N, Teng F, Zou C, Xue Y, Yang M, Song $\mathrm{H}$, et al. Hemoglobin A1c levels and aortic arterial stiffness: the Cardiometabolic Risk in Chinese (CRC) study. PLoS One. 2012;7(8):e38485.

30. Kokkoris P, Chantziara C, Toloumis G. Correlation of glycosylated hemoglobin and glucose response to oral glucose tolerance test. Diabetes 2007;56(Suppl 1):A254. 